


\title{
On Two Sublimes
}

\author{
Jonathan Lamb
}

'A fashionable current theme', Fredric Jameson calls the sublime, 'rediscovered in the works of Edmund Burke and Kant.' He makes the remark in his essay 'Postmodernism, or the cultural logic of late capitalism', as he prepares to add his own variant of the sublime - the camp or hysterical sublime - to the growing heap of sublimes that are now discriminated in literary and cultural theory. ${ }^{1}$ In the United States the sublime has not needed rediscovery. Ever since it was theorised as a basis for Romanticism in the 18th Century, first by the British and then by the Germans, it has been kept reasonable steadily in the American eye, not simply by scholars like Samuel Holt Monk and M H Abrams, but also by critics such as Emerson, Wimsatt and Bloom, not to mention practitioners like the poet Allen Tate and the painter Barnett Newman. More recently the sublime has been the subject of some remarkable post-Freudian theorisations, chief among these being Thomas Weiskel's The Romantic Sublime and Neil Hertz's brilliant collection of essays, The End of the Line. What is interesting about Jameson's rediscovery of the sublime is that it coincides - or collides - with a notable addition to thinking about the sublime made not by an American but by a French philosopher and art critic, JeanFrancois Lyotard. Although Jameson does not mention his name in his essay on postmodernism, it is hard not to suspect Jameson of trying to neutralise Lyotard's sublime and then to appropriate it for his own radical purposes.

It is the relation between these two sublimes, the Jamesonian or hysterical and the Lyotardian, that I want to discuss here. But first I want to point out that a rediscovery of the sublime ought to include Longinus, who gets the credit of inventing the first of its fifty seven varieties some time in the second century, somewhere in the Middle East - it seems appropriate that the dating and placing of its origin should be so imprecise. Even his name is uncertain, whether Cassius, Dionysius, or even Longinus are his proper names.

Very briefly, the radical shift accomplished by Longinus which differentiates his work so sharply from that of Aristotle, Horace, and Quintilian, is his neglect of art's mimetic function in favour of its symptomatic force. The sublime in literature and oratory (and it is to these two branches of art that he limits his study) is the sign, trace or echo of a huge impression, whether formed internally from sheer
Jonathan Lamb is an Associate Professor of Eighteenth Century English at the University of Auckland. His book Stone's Fiction and the Double Principle was published in 1989.

1. Fredric Jameson, 'Postmodernism, or the cultural logic of late capitalism', New Left Review, 1: 46: 1984, pp. 5391.

opp. From William Blake's Safau, Sin and Death 
2. Longinus, On the Sublime, translated by William Smith, London, 1739, p. 19. magnanimity ('the greatest Thoughts are always uttered by the greatest Souls'2) or from some vast phenomenon beyond ourselves ('the Nile, the Ister, the Rhine, or still much more, the Ocean', p. 85). The sign or register of this impression will be a disturbance of form: exclamation, repetition, question, tautology or any other failure in logic and syntax - which Longinus groups together as the rhetorical figures of the sublime. These figures are symptoms of passion, and their effect is not to transfer to the reader's or the audience's mind a detailed image of what caused them, but to set up a sympathetic vibration which will eventually equal the magnanimity of the original response. Symptom, that is to say, doubles up as cause, so that the poet seems to be in the presence of whatever it is that moves him, and the minds of his audience, swelling in correspondent transport, mistake 'what was only heard [for] the Product of [their] own Invention' (p. 14). It is easy to see how imitation, the corollary of mimesis in classical criticism, is redefined by Longinus: the faithful copier, 'ravished and transported by a Spirit not his own' (p. 36), makes copies indistinguishable from originals.

It is evident even from this short account that Longinus is blurring important differences; for example, the difference between art and nature (are the figures of the sublime deliberate or spontaneous?), between the represented and the representor (does the sublime quality reside in the object, the subject or both?), between the author and his audience, between the original and its copy, between the prior and the posterior, between the high and the low, and so on. Nor are the political implications of this levelling of hierarchies avoided by Longinus, when he declares, 'That Democracy is the Nurse of true Genius; that fine Writers will be found only in this sort of Government' (p. 103). Here the Whig and American affiliations with the sublime are quite clear; and it is worth emphasising what they entail, because Jameson's fears about postmodernism go all the way back to Longinus. These fears revolve around confusions that were first properly broached by Addison, in his Spectator papers on 'The Pleasures of the Imagination.' He labelled the dynamic of these confusions 'the double principle.' It operates whenever we can view the same object in two lights, as nature and as art, as copy and as original, as the effect of design and as the effect of chance (No. 414). These cognitive puzzles are part an emotional ambivalence that attends the sublime, when 'the Horror or Loathsomeness of an Object' (No. 412) is mixed with the pleasure afforded by its novelty or by its representation in words, so that the sensibility is treated to a 'double Entertainment' as it skirts pain to arrive at that more exquisite pleasure Burke, building on Addison, was to call delight. Included in the economy of the double principle is a cooperation of the imagination and the reason, when 'the Fancy copies after the Understanding, and transcribes Ideas out of the Intellectual World into the Material' (No. 421). But there is an inequality in this relationship, noted by Addison and improved by Kant: 'The Understanding, indeed opens an infinite Space on every Side of us, but the Imagination, after a few faint Efforts, is immediately at a stand, and finds herself swallowed up in the Immensity of the 
Void that surrounds it' (No. 422). Here is the germ of Kant's reason, that superior power which disburdens the imagination of the threat of the unrepresentable by grasping it as an idea of infinity, accomplishing in the region of the supersensible an apprehension of greatness in itself. 3

In the first phase of his confrontation with the postmodern world Jameson is tormented by two things. The first is the impossible complexity, the un-navigable space, of the fourth machine age, where all sense of depth and distance have been obliterated in the endless and boundless production of signs which, having no referents in the real, practical world of human community and endeavour, erase the sense and memory of that world in proportion as their signifieds are supplanted by signifiers. If this is the infinite Jameson's imagination cannot grasp, its symptoms, or the figures by which it manifests its force, provoke him to fits of impatience and disgust that are much more specific. Here it is as if Addison's double principle had been transformed by Jameson into a state of affairs in which every positive term (nature, community, reality, intentionality, representation, articulation, history) is sucked into its opposite (art, isolation, illusion, chance, iconoclasm, repetition, the dehistoricised present) and rendered inert. The double principle that would accompany the appreciation of parody, where the recognition of the difference between the original and the copy gives it its point and makes it amusing, has (as Jameson sees it) been made irrelevant by pastiche, or by the play of simulacra, where there is no difference to interpret, just iteration without enhancement. Parody made blank.

He keys this disgust to at least four themes, all related in one way or another to the sublime: death, repetition, madness and allegory. Death is perhaps the most obvious, the 'king of terrors', as Burke calls it. Comparing van Gogh's picture of peasant shoes with Warhol's Diamond Dust Shoes, he calls the latter 'a random collection of dead objects ... as shorn of their earlier life-world as the pile of shoes left over from Auschwitz, or the remainders and tokens of some incomprehensible and tragic fire in a packed dancehall' (p. 60). It is striking how ungeneralised Jameson makes that image, loading it with particulars in defence as it were of a real, sensible world that has, like Auschwitz, been the site of a holocaust. The very texture of Warhol's picture intimates mortality, the coloured surface having been 'stripped away to reveal the deathly black-and white substratum of the photographic negative.' A similar effect is achieved by the statues of Duane Hanson, polyester figures that rebound upon those viewing them, so as to 'transform them also for the briefest instant into so many dead and flesh-coloured simulacra in their own right' (p. 76). Pastiche Jameson calls speech in a dead language, 'amputated of the satiric impulse', a sightless memento mori, 'a statue with blind eyes' (p. 65). This personification of the deathly impulse is completed in the long quotation he gives from Michael Herr's Vietnam recollections, called Dispatches. Caught up in the perpetual motion of the generic helicopter, the 'meta-chopper' which is the 'saver-
3. Immanuel Kant, Critique of Judgment, translated by James Creed Meredith, Oxford: Oxford University Press, 1952. 
4. Sigmund Freud, 'The Uncanny', Pelican Freud 14, Harmondsworth, 1985.

5. Edmund Burke, A Philosophical Enquiry into the Origin of our Ideas of the Sublime and Beautiful, ed. J T Boulton, Routledge \& Kegan Paul, 1958. destroyer, provider-waster, right-hand left-hand', Herr reports that he felt 'death, death itself, [was] hardly an intruder' (p. 85).

Jameson's thematisation of death is partly a glance at Burke, who, like Addison, had singled out Milton's allegory of Death as 'sublime to the last degree' because of its terrible equivocality:

The other shape,

If shape it might be called that shape had none

Distinguishable, in member, joint, or limb;

Or substance might be called that shadow seemed,

For each seemed either; black he stood as night.

(Paradise Lost, II, 666-670)

Death represents for Jameson all that is most alarming about obliterated differences. It also provides a point of ultimate reference for an associated theme of uncanny repetitions. Eyeless statues and artificial human bodies echo two of the motifs of Freud's celebrated essay on 'The Uncanny', where, in the process of offering a commentary on Hoffmann's strange story of 'The Sandman', he first elaborates the theory of the repetition compulsion. 4 His idea, worked out fully the following year in Beyond the Pleasure Principle (1920), is that repetition is a signal sent from the inmost core of the unconscious where an impulse more primordial than the sexual drive lurks; namely, the desire to return to an earlier, inanimate state of things, a longing for death. Hence 'Diamond Dust Shoes' has 'nothing to do with death or the death obsession or the death anxiety on the level of content', says Jameson, but much to do with all three at the level of an image endlessly and perfectly replicable. Underneath its brittle elegance, and underneath the commodification of culture as a whole, Jameson locates 'blood, torture, death and horror' (p. 57).

Repetition is a sign of madness as well as death. Once again Jameson moves in company with Burke. In the Enquiry repetition is first of all linked to those madmen who 'remain whole days and nights, sometimes whole years, in the constant repetition of some remark, some complaint, or song' (p. 74).5 Later it is associated with effects in architecture like the colonnade, where pillar after pillar 'repeats impulse after impulse, and stroke after stroke' (p. 141). Jameson's world of infinitely reproducible simulacra is likewise assimilated first to madness, then to architecture. The madness is schizophrenia. Those afflicted by it suffer, Jameson argues, a break in the signifying chain, and are left confronting isolated phenomena whose vividness, vastness, gloss and smoothness is typical of the simulacra of commodity culture. The architecture is John Portman's Bonaventura Hotel in Los Angeles, whose clients endlessly rise and fall in the huge elevators, and whose visitors perpetually traverse the shopping arcades without ever managing to shop. The hyperspace is like the schizophrenic's glossy vision of the infinite, except that it incorporates and disorients great numbers of people. 
Jameson's observations on this building are most intriguing, for he is more amused and fascinated than disgusted by it. At the same time it ties together for him the tormenting themes of the sublime - if death, repetition, madness and the uncanny - into the knot of allegory; for what Jameson witnesses in the Bonaventura, particularly in those gondola-like elevators that ceaselessly rise and fall, is an allegory, 'new reflexive signs and emblems of movement proper ... a transportation machine which becomes the allegorical signifier of that older promenade ... the designation of cultural production as its content' (p. 82). In one sense he merely advances an insight about myth that he has from Roland Barthes, who shows how to make an image of an image by transforming its signified into the signifier of a myth. Thus the past becomes postmodernist pastness; motion towards a given point is turned into motion for its own sake, or mobilism, like Herr's helicopter; clothes stop keeping the cold out and become the signifiers in the system of fashion. But here in the hyperspace - the space of space - there is a reminder not only of commodity fetishisation and mythologisation but also of the uncanny and the sublime. Freud says that 'an uncanny effect is often and easily produced when the distinction between imagination and reality is effaced, as when something we have hitherto regarded as imaginary appears before us in reality, or when a symbol takes over the full functions of the thing it symbolises' (p. 367). Herr must have had that sensation on the meta-chopper when he felt an imminent and entirely familiar meeting might take place between him and 'death, death itself.'

In the Longinian sublime this effect is produced when the confusions of subject and object and of copy and original combine to make a speech by Demosthenes (for example) enact its theme by being violent about violence. Its most frequent formula concerns Longinus himself, who is always sublime on the sublime, or, as Pope puts it, 'He is himself the great sublime he draws.' In short, by contriving simultaneously to be what he endeavours to represent, he becomes a personification in an allegory of the sublime. He is both agent and patient of the sublime, designation and content: he is the sublime itself. So is Death of course, who is simultaneously the victim of his own dart and the cause of death in others. Here is that absolute allegorical quality which Kant himself refers to as greatness in itself, or 'greatness comparable to itself alone' (Critique of Judgement, p. 97). In a most astute analysis of the role of personification in the sublime, Stephen Knapp observes that 'in many of the most striking instance of sublime personification, the agent's total dependence on its idea is matched by a reflexive consciousness of its idea: the personification is self-consciously obsessed with the grounds of its own allegorical being ... it knows itself with a symmetrical purity unmatched by anything in empirical consciousness' (Personification and the Sublime, pp. 33-4).6 The symptom, or figure, of the selfrealising power of allegorical agency beginning to exert itself is either a tautology ('the sublime is he and he is the sublime') or a pleonasm, as in hyperspace (space of space) or meta-chopper (chopper of choppers).
6. Stephen Knapp, Personification of the Sublime, Cambridge, Mass: Harvard University Press, 1985. 
7. Jean-Francois Lyotard, 'The Sublime and the AvantGarde', Artforum, 22: 8, 1984 .

8. Jean-Francois Lyotard, 'Complexity and the Sublime', Postmodernism: ICA Documents 4, London, 1986. See also 'Presenting the Unpresentable: the Sublime', Artforum, 20: 8, 1982.
Let us get back to Lyotard, whose view of the postmodern and of the sublime, while by no means identical with Jameson's, nevertheless maintains some instructive parallels with it. He identifies the danger of the postmodern producer of art objects in much the same terms: the allure of 'quotations, ornamentations, pastiches, kitsch and the baroque' when flattering 'the eclecticism of a sensibility enfeebled the multiplicity of forms and available objects' leads, he maintains, to reflection not of sublimity but of 'the spirit of the marketplace' ('The Sublime and the Avant-Garde', p. 43).7 Like Jameson, he also associates this false eclecticism with the bad infinity of repetition, glancing at Freud as he does so: 'I would say that the quotation of elements of past architecture in the new one seems to me to be the same procedure as the use of remains coming from past life in the dream-work as described by Freud.... This use of repetition or quotation \{requires a working through - what Freud called Durcharbdeitung.... If we give up this responsibility, it is certain that we are condemned to repeat, without any displacement, the modern neurosis, the Western schizophrenia' (Defining the Postmodern, pp. 6-7). Lyotard agrees likewise on the prominence of death in the postmodern sublime. Burke prompts us, he says, to rethink 'the importance of death in life, because terror (through many expressions - lack of light, lack of words, lack of sounds) is a feeling of the imminence of death. With the sublime, the question of death enters the aesthetic question', (Complexity and the Sublime, p. 10). 8

From this point Lyotard and Jameson begin to diverge, and the divergence becomes more marked as they explore the duties of a thinker experimenting with the sublime under the threat of allegory. As far as Lyotard is concerned these duties comprise two questions, 'What is painting/writing/criticism?' and 'Is it happening?' This last question is posed in a 'now' very different from Jameson's unanchored schizophrenic moment; it forms part of a rigorous commitment to a quixotic project, the presentation of the unpresentable, in which the questioner is alert to the mixed feelings such a futile enterprise inevitably prompts. Lyotard describes there in Kantian terms: 'This frustration of expression kindles a pain, a kind of cleavage within the subject between what can be conceived and what can be imagined. But this pain in turn engenders a pleasure, in fact a double pleasure: the recognition of the impotence of the imagination contrarily attests to an imagination striving to illuminate even that which cannot be illuminated, and the imagination thus means to harmonise its object to reason - and furthermore the inadequacy of images, as negative signs, attests to the immense power of ideas. These unruly powers give rise to an extreme tension (Kant's agitation) which sets the pathos of the sublime apart from the calm sense of beauty' (SAG, p. 40).

Lyotard is quite willing to pay the price of a widening gap between the world of the senses and the world of these amazing ideas. Answering a question put by Terry Eagleton, whose Marxism is of roughly the same cast as Jameson's and who wanted 
to know if by the 'sublime' Lyotard simply meant 'anti-Leninism', Lyotard points out, 'Nobody has ever seen a society. nobody has ever seen a beginning. An end. Nobody has ever seen a world ... We must consider these Ideas as Ideas if we are to avoid illusion.' He might have added, if we are to avoid allegory, which is precisely the confusion of a general idea with empirical data, the invention of an idea which can do things, accomplish itself and change the world. Hence the monstrous danger of a politics of the sublime, when we make 'the terrible mistake of trying to present in political practice an Idea of Reason. To be able to say, 'We are the proletariat,' or 'We are the incarnation of free humanity,' and so on' ('Complexity and the Sublime', p. 11).

Specifically Lyotard is warning us against personification, that transformation which occurs (to quote Freud again) 'when something that we have hitherto regard as imaginary appears before us in reality, or when a symbol takes over the full functions of the thing it symbolises.' That is why it is crucial that the sublime questions be rigorously posed, for if they yield a jot to nostalgia, so that 'Is it happening?' is replaces by 'Is Siegfried coming?' then 'the aesthetic of the sublime [is] neutralised and converted into a politics of myth.' The allegorisation of ideas and the politics of myth are in effect the same thing for Lyotard: they are pure terror. What stands between us and that terror is the iconoclasm of the sublime, the inevitable but exciting failure of the project of representation, the impossibility of mimesis. The gap between ideas and things ensuring this impossibility Lyotard calls le différend, 'the unstable state and instant of language when something which must be able to be put in phrases cannot yet be. 9

With this in mind let us now see what Jameson does with his sublime. Remember I suggested that Jameson interprets the symptomatic confusions of the sublime, and the double principle they conform to, in a persistently negative, univocalising way, so that there is no tension, no Kantian agitation, no Burkean emotional ambivalence, no Addisonian double entertainment to be had out of them. Nevertheless he keeps pointing to intensities, euphorias, energies, hallucinatory highs - to some species of pleasure that accompanies the navigator's painful sense of lost coordinates. This is to be the alibi for a Marxising of the sublime, when Jameson will testify to his sense of the co-presence of pleasure and pain. Having identified the hyperspace of the Bonaventura as the scene of the allegory of a depthless and distanceless world, he then allegorises the allegory, taking it 'as the symbol and analogue of that even sharper dilemma which is the incapacity of our minds to map the great global multinational and decentred communicational network in which we find ourselves caught.' That is to say, the transformation of movement into mobilism, which ought to bring the mind to a Kantian halt and set up the limitless play of signifiers and simulacra, turns out to be an interpretatable symbol of an altogether different set of movements. To the imagined cry, 'What is happening?' Jameson responds, 'The Marxist dialectic', for it is Marx who
9. Jean-Francois Lyotard, 'The Differend, the Referent, and the Proper Name', Diacritics, Fall, 1984, p. 10. 
10. Frederic Jameson, Marxism and Form, Princeton: Princeton University Press, 1971. rediscovers Addison and Kant. 'In a well known passage, Marx powerfully urges us to do the impossible, namely to think this development positively and negatively at once; to achieve, in other words, a type of thinking that would be capable of grasping the demonstrably baleful features of capitalism along with its extraordinary and liberating dynamism simultaneously, within a single thought, and without attenuating any of the force of either judgement. We are, somehow, to lift our minds to a point at which it is possible to understand that capitalism is at one and the same time the best thing that has ever happened to the human race, and the worst' (p. 86). If this sounds very like Herr's experience of the meta-chopper (saver-destroyer, provider-waster, right-hand left-hand'), it is because Jameson has both politicised and re-allegorised the sublime, reading it as a moment in the Utopian narrative of Marxist history. The personified idea under whose agency this narrative unfolds is the Dialectic. Long ago Jameson defined the dialectic as tautological, and added, 'What is meant goes deeper than mere logical tautology ... here the identity is not between two words, or two concepts, but rather between subject and object itself, between the process of thinking and very reality on which it is exercised'10 (Marxism and Form, p. 341). This is very close indeed to what Lyotard calls terror, the feeling we have when threatened with absolute privation of 'death, death itself.' Terror is always incident to the efforts of self-sufficient, selflifting figures, whether personified abstractions or proper names, who claim to make the world a better place by transcending its contradictions.

It is interesting to wonder how many of these gestures of Jameson's are conscious, and how many are symptoms of a sublime encounter he truly cannot control, even with Dialectic. Altogether, at any rate, they add up to a comprehensive list of what Longinus would call figures of the sublime: repetition, a great number of quotations, and that allegorising shift which makes symbols, signs and images autoreferential and self-performing. The difference between Longinus and Jameson is that the ancient critic is under no illusions about the destructive forces of the sublime, and offers his figures as consolatory, reconstitutive echoes of the damage it causes. It is not tautologous identity that Longinus pursues by being sublime upon the sublime, rather a Durcharbeitung of the repetitions and doublings which are its most notable verbal symptoms.

Perhaps this distinction will sharpen by a comparison of Jameson's predicament with Wordsworth's. In the hyperspace he shares a confusion experienced by Wordsworth in the streets of London, in the region of Bartholomew Fair, where he suffered the same sort of disorientation experience by visitors to the Bonaventura Hotel. There Wordsworth was haunted by a miniature world which had turned into nothing but symbols and signs, an allegory of modern life which threatened to incorporate him as just another perambulating emblem. 
Oh, blank confusion! and a type not false

Of what the might City is itself

To all except a Straggler here and there,

To the whole Swarm of its inhabitants;

The slaves unrespited of low pursuits,

Living amid the same perpetual flow

Of trivial objects, melted and reduced

To one identity, by differences

That have no law, no meaning and no end.
11. Neil Hertz, The End of the Line, New York: Columbia University Press, 1985.

In the midst of this confusion suddenly he confronts a blind beggar, underneath whose sightless eyes and fixed face a label hangs, explaining 'the story of the man, and who he was', and Wordsworth feels admonished as if from another world. This figure has a lot in common with the Death who threatens to ride the meta-chopper, or with Duane Hanson's polyester figures, and he looks very like the image Jameson uses to characterise pastiche, 'a statue with blind eyes.' Neil Hertz takes the beggar to be a figure of minimal difference (between face and label) that is ance typical of the confusion of the fair and yet a consolation for it, an emblem of failed emblem-hood, a messenger of a vast allegorical narrative ('the utmost that we know. Both of ourselves and of the universe') which will remain untold. The difference between the face and the text is critical in preventing the tautology of a word identical with a thing; it sustains the instability of le differend, where phrases are always about to be uttered but never are. The beggar mirrors Wordsworth, then, but neither allegorises nor abolishes him. In all sublime scenarios, Hertz argues, 'what is repeatedly represented ... is a practically (but not quite) dispensable "subject" confronting a split or doubled "object"11 (p. 222). This inclines me to think that Jameson's most useful intuition is not of the dialectic under a sublime form but of two slices of mirror-glass building in specular confrontation, distorting, shivering, ruining one another as reflexions are despatched from 'one enormous glass surface to the other' (p. 79). It would almost be worth trading in one's monadic subjecthood to witness such a conflict between splitting glass objects in this town. 